\title{
Public Perception on Quality of Decision-Making Process by Female Leader of Southeast Minahasa Regency
}

\author{
Erna Hilda Mokat, Jetty Recky H E Sendouw
}

\begin{abstract}
Decision making is one of the duties of a leader, both leaders in public and private organizations. The research aims to analyze the public perception on the quality of the decision-making process by the female leader of the local government. Descriptive qualitative research method was employed, and the data was collected through observation, interviews and documentation. The results of the study show that the stages in decision making process had not been conducted properly. Decisions were not taken based on clear and accurate data and information that made it hard to be legally, morally and ethically accountable in the scope of administration. The aspirations of people received less attention, rarely involving subordinates, insufficient understanding of regulation causes nonprocedural, unconstitutional, and discretionary decisions. As a recommendation, it is necessary to conduct further research related to the decision-making process of female leaders.
\end{abstract}

Keywords: Leadership; Female Leaders; Decision Making; Southeast Minahasa.

\section{INTRODUCTION}

Every organization definitely needs a leader. The success or failure of an organization in achieving the goals is largely influenced by how the leader managing the organization. According to Keith Davis (1), "without leadership an organization is but a muddle of men and machines, and management activities such as planning, organizing and decision making are dormant cocoons until the leader triggers power of motivation in people and guides them toward their goals". The presence of a leader becomes very important because she does not only play a role in setting direction and targets of an organization, but also implementing organization's management in order to make the organization can reach the peak of success. The successful organization is a manifestation of the successful leader, and also illustrates how the quality of leadership influences the people she leads.

According to ${ }^{(2)}$, "leadership involves a process that is intentional influence is exerted over other people to guide, structure, and facilitate activities and relationships in a group or organization". This perspective implies the

Revised Manuscript Received on September 22, 2019

Jetty Erna Hilda Mokat, State Administration Study Program, Faculty of Social Sciences, Universitas Negeri Manado Indonesia 95618.

Recky H E Sendouw, State Administration Study Program, Faculty of Social Sciences, Universitas Negeri Manado Indonesia 95618. reckyhes@yahoo.com importance of relationship between leaders and those who are led in order to make the influencing process properly works. This process can be done well if a leader has the ability to not only influence and facilitate tasks within the organization, but also can adapt with subordinates in achieving the goals.

Decision making is the process and action of selecting the best decision from several alternatives based on consideration to solve problems as well as to obtain the best results. The results of each decision delineate the accuracy and quality of the choice. ${ }^{(3)}$ stated, "the quality of decision making in organizations relies on selecting the right objectives and identifying the ways to achieve them" whereas according to ${ }^{(4)}$ "quality is about the quality of work or the results that have been achieved with the process within it. So that the quality of the decision comes from the results of the decision that has been applied or tested maximally with the maximum result and value as well'" Thus, it can be said that decision making, a process of selecting among a series of alternatives, is highly needed by a leader, because the key to success of an organization is determined by the leader as a determinant of the direction and goals of the organization. Moreover, as stated by ${ }^{(5)}$ that "the process of decision does not come to an end when the general purpose of an organization has been determined". Thus, decision making will continue as long as the organization exists, and as long as it exists, it still needs a leader.

Leaders in government organizations are generally dominated by men, although there is no provision that to become a leader someone must be a man. The men and women have the same opportunity to be leaders, but also have their own strengths and weaknesses. It means that anyone can be a leader. It must be acknowledged that is currently the numbers of women who sit in the position of top leaders are increasing though their representation in the public sphere is still far from expectations. However, this condition has not yet been able to resolve various gender issues, including injustice and inequality in gaining opportunities on government and political sector especially in the developing countries like Indonesia.

The perception that women are not fitted to take a leadership, particularly for the top leader position, is more due to gender issues. The inherent characteristics of women as meek, emotional, sensitive and less assertive are among others the reasons they are less

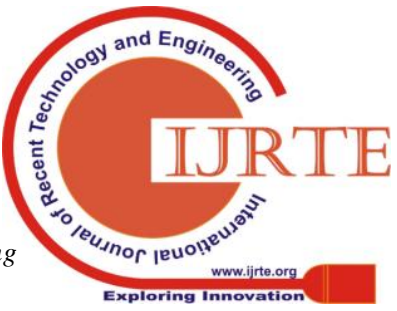


suitable to become public leaders who are full of violence and challenges because of many tasks must be resolved like duty and function as decision makers, whereas a successful leader is not determined by gender, it is more related to the values of leadership, intelligence, skills and talents.

Southeast Minahasa is one of the regencies in North Sulawesi Province that had been led by a woman. As the head of the district, she certainly had inherent authority including the authority of making decisions. Every decision certainly has consequences that greatly determine the continuity of the organization she led. Regarding to the function as a decision maker, it is expected that a head of the local government to have adequate knowledge, expertise, abilities and skills that can support the decision-making process.

The study found that decision-making taken by the female head of Southeast Minahasa did not reflect the quality of decision making but evoked the controversy and resistance from both people and subordinates. The resistance is related to the unfair shake-up mechanism of the apparatus within the organization; decision making without involving the subordinate; unilateral decision of changing official symbol of the district, relegation of potential official, and rarely involved the Vice Regent in decision making. As an internal supervisor within the government, the Vice Regent was disregarded that affected the regency obtaining disclaimer predicate until the end of Regent's tenure.

The information above shows that the decision of the female regent was still far from expectations. As a leader, the regent actually should act according to the provisions for the progress of the organization or region by considering the interests of the people she led. Therefore, this study tries to deeply examine the public's perception of the quality of female head of local government in terms of the decision-making process.

\section{Literature REVIEW}

According to ${ }^{(2)}$, "leadership involves a process that is intentional influence is exerted over other people to guide, structure, and facilitate activities and relationships in a group or organization". This perspective implies the importance of relationship between leaders and those who are led in order to make the influencing process properly works. This process can be done well if a leader has the ability to not only influence and facilitate tasks within the organization, but also can adapt with subordinates in achieving the goals.

Decision making is significantly important as inseparable part of leaders' activities and becomes one of the keys to the success of an organization's leaders. It is even regarded as a basic function of leadership. Every organization is dealt with kinds of activities and problems that require solutions as an effort to achieve goals, so it is imperative for leaders to make the right decisions. Therefore, a leader is required to have adequate knowledge, abilities, and skills, in addition to knowing and understanding the basic problems in order to be able to make the right decisions. (6) assert that "decision making has fundamentally influencing performance". This is understandable because the effectiveness and quality of leadership will be seen in the results of decisions, and it will have an impact on individual and organizational performance respectively.

Decision making is the process and action of selecting the best decision from several alternatives based on consideration to solve problems as well as to obtain the best results. The results of each decision delineate the accuracy and quality of the choice. ${ }^{(3)}$ stated, "the quality of decision making in organizations relies on selecting the right objectives and identifying the ways to achieve them" whereas according to ${ }^{(4)}$ "quality is about the quality of work or the results that have been achieved with the process within it. So that the quality of the decision comes from the results of the decision that has been applied or tested maximally with the maximum result and value as well". Thus, it can be said that decision making, a process of selecting among a series of alternatives, is highly needed by a leader, because the key to success of an organization is determined by the leader as a determinant of the direction and goals of the organization. Moreover, as stated by ${ }^{(5)}$ that "the process of decision does not come to an end when the general purpose of an organization has been determined". Thus, decision making will continue as long as the organization exists, and as long as it exists, it still needs a leader.

\section{Methodology}

This study was conducted in the Local Government of Southeast Minahasa, North Sulawesi Province, using a qualitative approach with case study research design. The purpose of the study is to describe and analyze public perception on the quality of female Leader's decision-making focused on the decision-making process. Data sources were obtained from informants who were selected by purposive sampling technique which included the Regency Secretary, expert staff, inspectorate, Head of Department/Agency, Head of Public Agency, Religious Leaders, NGOs, and members of Local House of Representatives. The data was collected through observation, in-depth interviews and documentation while in analyzing the data it was used qualitative descriptive analysis technique with interactive models from Miles and Huberman ${ }^{(7)}$.

\section{RESULTS AND FINDINGS}

To find out the public perception on the quality of regent's decision making, the study was focused on the decision-making process. The decision-making process is an activity of selecting the alternative decision from a number of available alternatives. In order to make decision based on the objectives, however, the process needs the following stages: 1) search environment for conditions calling for a decision; 2) analyze alternative problems and solutions; 3) select particular alternative among available alternatives; and 4) implement the decision.

The results of the study show that the first stage, which

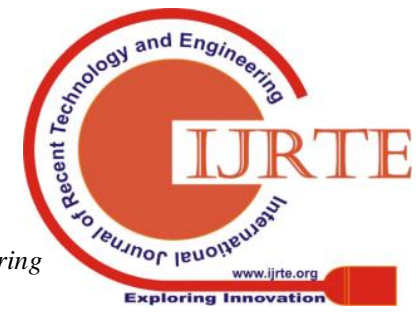


is the search environment for conditions calling for a decision, has not been fully conducted. At this stage the collected data is identified to find out more about the problems faced. In contrary, the process of identification was not conducted objectively. Basically, before making a policy, the deliberate planning and analysis should be done along with expert staffs and competent parties. One of the examples is the decision of changing the symbol of the regency which evoked the controversy and resistance from various parties. This happened because the decision was not preceded with in-depth studies on the need to change the symbol, as well as what people wanted or hoped for. In this case, besides of not receiving input from subordinates, the regent also ignored the input from the people.

According to Finch and McGough (8) "participatory decision-making is more beneficial because this approach considers the ethics and personal enthusiasm, it has the opportunity to get strong support in the form of active involvement from related professional staff", As a policymaker, the leader should righteously respond to the changes and resources in society by searching and finding out the obstacles then developing the alternative solutions as assurance of organizational accountability. The lack of searching, identifying, developing and analyzing the problems cause the decisions taken are not based on existing provisions, but rather on discretionary decisions without a legal provision. The discretionary power is actually an extension of the function that gives government a freedom to act in the sense that freedom has limitations and can be accounted for. Legal restrictions on government discretionary power according to ${ }^{(9)}$ are mandatory as a guarantee for the basic legitimacy of all citizens, and accountability is the consequence under the notion of rule of law.

Second, analyze the problem. This stage is meant to collect the data based on clear information, and furthermore making an analysis to find alternatives, evaluate problems and find solutions for appropriate response and resolution. The lack of information rendered the available data become less supportive. Moreover, the deteriorated relationship with subordinates and community leaders who could be used as sources of information made the information obtained was very minimal. As a policy maker, the regent should search and find out what the obstacles are, then select alternative solutions by considering that the needs of the people are very complex, so it needs to take a rational approach in making choices, rational with reasons, and oriented to the public interest. Basically, information is a very important element in decision making. It means that information should be true, clear, accurate and up-to-date to be accounted for. As how important and meaningful information for decision makers, Davis in ${ }^{(8)}$ states that "information is data that has been processed into a meaningful form for those who use it and have meaningful value for decision making". The Information can be obtained from relevant parties who really know the problem so that it can be source of study that can be compared with other information in order to reduce the level of uncertainty.
Third, the stage of selecting alternative is an action of making a decision by selecting one of the best alternatives with the least amount of risk but having a chance to succeed with great benefits. At this stage it is required a leader who has the courage to take risks of the decisions. Taking decisions is an important and inseparable part of the leader, including the head of local government. The results showed that the female regent who had led the Southeast Minahasa Regency tended to be unconstitutional which rendered the violations of regulations and maladministration, such as the nonprocedural decision of a shake-up in structural positions impacted to public servant's performance and organizational performance, which depicted how the quality of a regent to make a decision. The quality of the decision or the decision of a leader / regent is very dependent on the ability to determine the right choice from several alternative choices.

The ability to make decisions will reflect the quality of a leader. Robbins in ${ }^{(10)}$ confirms that personal quality is important for the effectiveness of decision making. Four things related to personal quality, are "experience, positive judgment, creativity, and quantitative skills". The experience will help to improve a person's ability to act critically and precisely. Assessment as an important element for evaluating every problem emerged, and creativity is the ability, skills and strong personality possessed in assessing and organizing problems rationally while quantitative skills are related to the ability to carefully and carefully manage the problems within the organization to be useful and capable of providing maximum results.

Fourth, the implementing the decisions is the stage of implementing the choice. The involvement of subordinates or followers during decision making is closely related to implementation activities, especially about commitment to implement decisions. The involvement of others, such as subordinates, expert staff, and community leaders, is one of the prerequisites for the quality of a decision. Through the involvement of other parties, leaders will get more clear and assured information and ultimately a qualified decision. At this stage, the quality and ability of leaders is also at stake through managerial ability to make consensus with subordinates in order to create commitments while considering the impact of implementation, and activity plans, monitoring and evaluating activities.

\section{Conclusion}

Based on the results and discussion, it can be concluded: 1) the stages in the decision-making process had not been conducted properly. 2) Decisions were not taken based on clear and accurate data and information that made it hard to be legally, morally and ethically accountable in the scope of administration. 3) Clear, accurate and up-to-date information was difficult to obtain because it was not given the opportunities to subordinates and the people as sources of data and information to express views / opinions, consequently, there was resistance towards the decisions because the decisions did not meet the 
needs and expectations of the public; 4) lack of knowledge on regulation that had an impact on unconstitutional and maladministration actions; 5) tended to make discretionary decisions, but did not meet the legal requirements of a discretion.

\section{REFERENCES}

[1] Hicks G Herbert GRG. Organisasi Teori dan Tingkah Laku. Jakarta: Bina Aksara; 1987.

[2] Yukl G. Kepemimpinan dalam Organisasi [Internet]. 5th ed. Jakarta: Indkes; $2010 . \quad$ Available from: https://www.tokopedia.com/tokobuku20/buku-kepemimpinan-dalam-or ganisasi-edisi-5-oleh-gary-yukl? $\mathrm{c}=1869388532 \& \mathrm{~m}=137483646 \& \mathrm{p}=2$ 97580659\&ds_rl=1270598\&gclid=EAIaIQobChMI1pCj4fzD4wIVzY BwCh1EIQ5nEAQYAyABEgJUffD_BwE\&gclsrc=aw.ds\&ef_id=XGq -uAAAAIJgX2Yh:20190720170206:s

[3] Ivancevich, John, M D. Perilaku dan Manajemen Organisasi. 1st ed. Jakarta: Airlangga; 2008.

[4] Irham F. Manajemen Pengambilan Keputusan. Teori dan Aplikasi. Bandung: Alfabeta; 2011.

[5] Simon HA. Administrative Behavior. Perilaku Administrasi, Suatu Studi tentang Proses Pengambilan Keputusan dalam Organisasi Administrasi. Jakarta: Bina Aksara; 1982.

[6] Donnelly, J. H., Gibson, J. L., Ivancevich, J. M., Dolanský, V., \& Koubek J. Management. Grada; 1997.

[7] Miles, Matthew, B \& Huberman, Michael A. Qualitative Data Analysis. Jakarta: University of Indonesia Press; 1992.

[8] Djatmiko YH. Perilaku Organisasi. Bandung.: Alfabeta; 2008.

[9] Darumurti KD. Kekuasaan Diskresi Pemerintah. Bandung: Citra Aditya Bakti; 2012

[10] Arismunandar. Perilaku Organisasi dalam Pendidikan. 1st ed. Makassar: Badan Penerbit UNM; 2008.

\section{AUTHORS PROFILE}

My name is Jetty Erna Hilda Mokat,I am doing State Administration Study Program, Faculty of Social Sciences, Universitas Negeri Manado Indonesia 95618.my area of interest is social science.

My name is Recky H E Sendouw, I am doing State Administration Study Program, Faculty of Social Sciences, Universitas Negeri Manado Indonesia 95618.my area of interest is social sciences. 